\title{
フィールドワーク研究と実験研究を基にした重金属によって 誘発された疾患の機構解明と浄化法の開発
}

\author{
矢嶋伊知朗, Cunchao ZOU, Xiang LI, 中野 千尋, \\ 小又 尉広, 熊坂真由子 \\ 名古屋大学大学院医学系研究科環境労働衛生学
}

\section{Analysis of Heavy-Metal-Mediated Disease and Development of a Novel Remediation System Based on Fieldwork and Experimental Research}

\author{
Ichiro YAJIMA, Cunchao ZOU, Xiang LI, Chizuru NAKANO, \\ Yasuhiro OMATA and Mayuko Y. KUMASAKA \\ Department of Occupational and Environmental Health, Nagoya University Graduate School of Medicine
}

\begin{abstract}
Heavy-metal pollution occurs in various environments, including water, air and soil, and has serious effects on human health. Since heavy-metal pollution in drinking water causes various diseases including skin cancer, it has become a global problem worldwide. However, there is limited information on the mechanism of development of heavy-metal-mediated disease. We performed both fieldwork and experimental studies to elucidate the levels of heavy-metal pollution and mechanisms of development of heavy-metal-related disease and to develop a novel remediation system. Our fieldwork in Bangladesh, Vietnam and Malaysia demonstrated that drinking well water in these countries was polluted with high concentrations of several heavy metals including arsenic, barium, iron and manganese. Our experimental studies based on the data from our fieldwork demonstrated that these heavy metals caused skin cancer and hearing loss. Further experimental studies resulted in the development of a novel remediation system with which toxic heavy metals were absorbed from polluted drinking water. Implementation of both fieldwork and experimental studies is important for prediction, prevention and therapy of heavy-metal-mediated diseases.
\end{abstract}

Key words: heavy metal (重金属), fieldwork（フィールドワーク）, experimental study（実験研究）, cancer (癌), drinking water（飲用水）

緒 言

重金属による環境污染は自然発生から人為的(産業的) 発生まで，様々な原因によって引き起こされる。中でも 飲用水に関わる污染は, 安全な水の確保を阻害し, 人々

受付 2014 年 10 月 15 日，受理 2014 年 10 月 28 日

Reprint requests to: Ichiro YAJIMA

Department of Occupational and Environmental Health, Nagoya University Graduate School of Medicine, 65 Tsurumai-cho, Showaku, Nagoya, Aichi 466-8550, Japan

TEL: +81(52)744-2125, FAX: +81(52)744-2126

E-mail: yajimai@med.nagoya-u.ac.jp
の健康に大きな影響を及ぼしている。飲用水の重金属污 染は深刻な問題の 1 つであり，世界中で深刻な問題と なっている (1)。中でも飲用井戸水の七素污染はアジア・ アフリカ及び南米地域の広範囲にわたって広がって拉 り，癌を含む多くの疾患発症の原因となっている。例光 ばバングラデシュでは 2,500 万人， ベトナムでは 1,100 万人もの人々が慢性七素中毒を発症している $(2,3)$ 。ま た，メキシコ及びチリで各 40 万人，アルゼンチンで 20 万人，ガーナでは 10 万人の人々が，安全でないレベル の七素に曝露している(4)。慢性的な七素の曝露は皮膚 癌や肺癌, 膀胱癌, 肝癌等の発症を誘導し, 人々の健康 だけでなく，生命をも脅かしている(4)。近年は飲用井 
戸水には七素だけではなく, 様々な重金属によって複合 的に污染され，新たな疾患発症因子として注目されてい る (5-10)。このような背景から, 飲用井戸水の重金属 污染について，七素だけでなくその他の重金属との複合 污染に着目し, その実態や疾患発症機構の解明, またそ れらの浄化法を開発することは, 重金属によって誘発さ れた疾患の予知・予防法の開発繋がり, 安全な水をよ り多くの人々が享受するための極めて重要な研究である といえる。筆者らはこれまで, 飲用井戸水の重金属污染 について様々なアプローチ方法を基に研究を行ってきた (5-14)。これらの研究の多くは衛生学的研究に打いて必 須のフィールドワーク研究と, 培養細胞や実験動物を用 いた実験研究を組み合わせることによって成立してい る。本稿では, 重金属によって誘発された疾患汇関して, 特に飲用井戸水潐点を当て，筆者らが現在行っている フィールドワーク研究及び実験研究によって得られた重 金属污染実態と関連疾患発症機構，新たに開発した重金 属浄化法ついて紹介するとともに，フィールドワーク研 究だけでなく, 実験研究を同時に行うことによる利点, 可能性，また課題について述べたい。

\section{飲用井戸水重金属污染の実態}

飲用井戸水の重金属污染について, これまで多くの研 究が七素に焦点を当てて行われてきたが, 近年, 筆者ら はヒ素以外の重金属による污染について幾つか報告を 行った。バングラデシュ, ベトナム, マレーシアの井戸 水や, 污染された水を飲用している現地居住者の毛髪, 爪，尿に含まれる，重金属を含む様々な元素含有量を ICP-MS を用いて測定し，七素以外飞もバリウム，鉄， マンガンといった元素が安全ではないレベルで含まれて いることが明らかとなった $(5,6,8,10,12)$ 。また，井戸 水に含まれるこれらの元素の中には, 鉄やバリウムのよ らに七素含有量と正の相関関係を示す元素も存在し, 飲 水によってヒ素に曝露される場合, これら他の重金属に も曝露される可能性が高いことを示している $(5,6,12)$ 。

\section{飲用井戸水に含まれる重金属元素の毒性}

フィールドワーク研究によって明らかとなった, 飲用 井戸水に含まれる重金属元素の毒性を明らかにするた め, 筆者らは実験動物や培養細胞を用いた曝露実験を行 い, 主に聴力異常と発癌に関する研究を行った。バリウ ムの聴力に対する影響については, 3 週齢 ICR マウスに 12.5 及び $125 \mu \mathrm{M}$ の塩化バリウムを 2 週間领水投与し, 聴性脳幹反応 (Auditory Brain-stem Response; ABR) 測定 によって聴力への影響を調查した。その結果, 測定した $4,12,20,32 \mathrm{kHz}$ のらち，4，12，20 kHz で聴力低下 が観察され，同時に内耳有毛細胞及び蝸牛神経節に形態 的異常が観察された（15）。

バリウムの発癌毒性については，七素を含む飲用井戸
水に上る発癌の中でも皮膚癌に注目し，七上皮膚角化細 胞株（HaCaT）（16）を用いた培養細胞実験を行った。 $\mathrm{HaCaT}$ 細胞に 5-50 $\mu \mathrm{M}$ の塩化バリウムを24-48 時間曝露 したところ, 癌化した細胞に特徵的な足場非依存的增殖 と浸潤能活性が上昇し, 癌関連分子である c-SRC, FAK, ERK $1 / 2$ のリン酸化レベルの上昇を伴っていた (8)。また, $5 \mu \mathrm{M}$ の塩化バリウムを $\mathrm{HaCaT}$ 細胞に 4 ヶ月間長期曝露 したところ, 不可逆的な足場非依存的增殖の活性化が観 察されたことから，バリウムは少なくとも七ト皮膚正常 角化細胞株に対して, 癌化した細胞洔牧的な複数の表 現型を示すことを明らかにした（9)。これらの結果は， これまで知られていなかったバリウムによる毒性を示す ものであり，飲用井戸水による重金属曝露の影響につい て，バリウムの影響を考慮する必要性を示唆している。

\section{ヒ素による毒性発露における，他の重金属の影響}

フィールドワーク研究によって明らかになったよう に，七素污染された飲用井戸水には，他の毒性重金属元 素によっても同時に污染されている可能性が高いが，こ れらの重金属が，七素によって発露される毒性に対して どのよらな影響を及活すのかは明らかになっていない。 筆者らはヒ素による皮膚癌発症に打汀る他の重金属元素 の影響を明らかにするため, $\mathrm{HaCaT}$ 細胞又はヒト皮膚 扁平上皮細胞株 (A431, HSC-5)にヒ素と同時にバリウム, 又は鉄を複合曝露し，その影響を解析した。七素は発癌 毒性の他に細胞毒性（細胞死誘導）も持つため，七素を 高濃度で曝露すると, 全ての細胞が細胞死を呈するが, バリウムを同時に曝露すると A431 及び HSC-5 細胞では 七素誘導性細胞死が抑制され, $\mathrm{HaCaT}$ 細胞では細胞死 抑制は観察されなかった。A431 及び HSC-5 細胞への複 合曝露では, NF- $\mathrm{BB}$ の活性化とともに, XIAP の発現上 昇とJNK1/2 の活性阻害が観察された。JNK1/2を介した 細胞死誘導シグナルは NF- $\mathrm{BB}$ 活性化によって発現誘導 された XIAP が阻害することが知られている $(17,18) こ$ とから，バリウムはヒ素によって誘導される皮膚癌細胞 の細胞死を抑制していることが明らかとなった。また， 正常皮膚角化細胞株である $\mathrm{HaCaT}$ ではこのような細胞 死抑制は観察されなかった（10）。前述したよらに，七 素は発癌毒性と細胞毒性の両方の特性を持つ元素であ り, 正常細胞を癌化させるとともに, 癌細胞を細胞死誘 導する。しかし，バリウムの共存在下では細胞死誘導が 阻害され，本来細胞死誘導されるはずの皮膚癌細胞が生 き残ることになる。これは七素によって誘導された皮膚 癌細胞がバリウム共存下ではより多く生き残ることを示 して扣り, 七素単独の曝露よりも, 七素とバリウムの複 合曝露の涪らが発癌, 或いは癌の悪性化リスクが高いこ とを示唆している。

七素と鉄の複合曝露は, バリウムの場合と少し異なる。 筆者らのフィールドワーク研究の結果, 七素污染された 井戸水では鉄にも同時に污染されており，その濃度比は 
モル濃度で注涪1：10 の関倸にあることが判明した。こ の濃度比を維持して $\mathrm{HaCaT}$ 細胞への曝露実験を行った 結果, 足場非依存的増殖と浸潤能活性が, 七素単独瀑露 による効果よりも相乗的に活性化していることを明らか にした。また，発癌及び浸潤に関与する細胞内シグナル 分子である SRC 及び ERT $1 / 2$ も同様汇活性化しているこ とが明らかとなった。これらの結果は, 七素単独曝露よ りも, 鉄との複合曝露のほうが皮膚癌発症のリスクが高 い可能性を示唆している。また，このような七素と鉄の 複合曝露に上る効果は, 七上皮膚扁平上皮細胞株 (A431) に対しても引き起こされたことから, 皮膚癌が発症した 後の悪性化, 浸潤のリスクもまた複合曝露のほらがより 高い可能性を示唆している(6)。

\section{ハイドロタルサイト様化合物を用いた 匕素複合污染水の浄化法開発}

前述したフィールドワーク研究や実験研究を推し進め れば, 七素及びその他の重金属に污染された飲用水に よって引き起こされる癌等の疾患を予知し, 明らかと なった発症メカニズムを応用した予防法や治療法を開発 することが可能となる。このようなアプローチは極めて 論理的であり, 妥当な方法論ではある（実際に筆者らは このよらなアプローチを実行している）が，一方で, 疾 患の原因となる環境因子を取り除くことができれば，少 なくともその後の関連疾患の発症リスクを限りなくゼロ に近づけることになる。このような考光から，筆者らは 七素及びその他の重金属によって污染された水を浄化す る方法について検討を行ってきた。これまで報告され ている例として，八イドロタルサイト（様）化合物を利 用した浄化法がある。八イドロタルサイト（HT）はマグ ネシウムやアルミニウム等の金属イオンを成分に持つ層 状複水酸化物の一つで, アニオン交換機能と, カチオン 吸着機能を有している。これまでにも，七素を始めとし て, カドミウム, 鉛, ニッケル, クロム等が実際に浄化 可能であることが報告されている(19-21)。筆者らは, マグネシウムと鉄をベースとした八イドロタルサイト様 化合物（MF-HT）を新たに作成し，七素及びその他の毒 性重金属元素の吸着試験を行った。七素の場合, 初濃度 $500 \mu \mathrm{g} / \mathrm{L}$ （WHO 飲料水水質ガイドライン：10 $\mu \mathrm{g} / \mathrm{L}$ ）を 15 秒以内に $99.9 \%$ 以上除去が可能であり, 前述した鉄 やバリウムに対しても高効率で除去が可能であった。ま た，前述した七素との複合污染を考慮し，七素・鉄或い はヒ素・バリウム混合液に対しても, 添成様の除去率 を示した。さらには, バングラデシュやベトナムで実際 飞使用されて和り, 七素や鉄, バリウムに複合污染され ている井戸水（污染レベルはヒ素: 90.3-459.3 $\mu \mathrm{g} / \mathrm{L}$, 鉄：

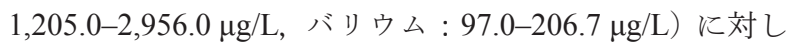
ても同様の試験を行ったところ, 上記の結果とほぼ同様 の除去能力を示した $(5,6)$ 。これらの結果は, 筆者らが 新たに作成した MF-HT はヒ素污染水を速やかに且つ効
率的に浄化することが可能だけでなく，七素との複合污 染によって疾患発症リスクを持つ鉄やバリウムも，七素 と同時に浄化が可能であることを示唆している。また， これ迄涬報告されている，HTを用いた七素吸着試験で は，十分なと素の除去に 10-16 時間必要であった（19） ことから，筆者らが作成した MF-HT の 15 秒以下とい ら除去スピードは, 極めて高率の高い吸着剂であるとい 光る。現在は実験系での試験のみであるが，将来的には より大規模な除去システムを構築し, 直接, 現地の污染 水に対して行うことで, 実用化を進めていく必要がある と考光らる。

\section{フィールドワーク研究と実験研究の相互作用}

衛生学におけるフィールドワーク研究と実験研究を同 時に実践するためには，包括的な計画と相互のフィード バックが重要である。著者らが行った, 或いは現在行って いる重金属污染関連疾患济関する研究に打ける, フィー ルドワーク研究と実験研究の位置づけを図 1 亿示した。 本研究の出発点は, 衛生学の基本であるフィールドワー クによって環境及び生体内の重金属を測定することで, 污染されている元素の種類及びそのレベルを明らかにす ることから始まる。このデータそのものが污染実態の一 部を解明することになるが，その毒性をより詳細に検討 するための実験研究の基礎データとしても利用される。 実験研究に打いて, 培養細胞実験と動物実験は重金属の 毒性を評価し，その発症メカニズムを解明するために有 効な手法である。培養細胞実験は毒性発症メカニズムを 分子細胞生物学的に解析する上で重要であり, 特に複合 污染のように，実験条件が複雑で多岐にわたる場合には 培養細胞実験が有効である。培養細胞は基本的に単一の 種類の細胞であり, 重金属曝露に対する反応が一様で, その表現型を高い感度で検出できる。また, 細胞内で引 き起こされる様々な反応 (遺伝子発現, 遺伝子変異, エピ ジェネティック変異, タンパク質の量的変化や活性変化 なぞ）も一様なため，バックグラウンドの低い検出が可 能である。しかし，重金属は直接培養細胞に曝露するた め，飲水による曝露等を想定した場合，その重金属が実 際に標的の臓器（細胞）飞到達する際の化学形態や濃度 に注意する必要がある。一方, 動物実験は七トの飲水に よる曝露を再現させるため，体内での吸収や排出，重金 属の修飾等が七トと同様に起こっていると仮定できれば, 非常に有効な手法である。生体としての毒性の発露, 組 織学的な解析による形態変化や遺伝子・タンパク質の発 現及び活性の変化を検出することが可能である。培養細 胞実験, 動物実験による解析によって, 重金属の毒性の 解明や，その発症メカニズムの解明が可能となり, 分子 レベルの予知/診断マーカーを見出すことも可能である。

上述の生物実験の他に, 水を浄化するための浄化剂開 発を目的とした化学実験も行っている。八イドロタルサ イトは特殊な構造を持つだけでなく, 合成に必要なコス 


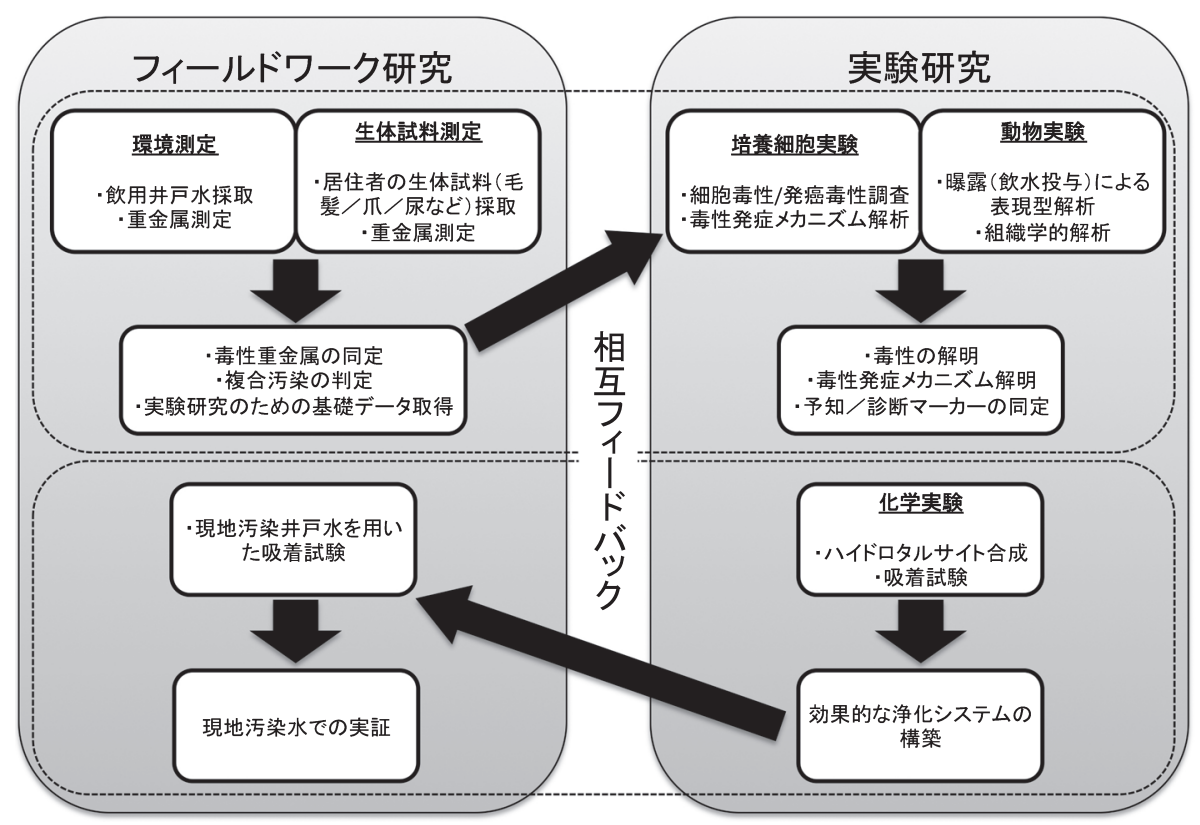

図 1 重金属污染関連疾患に関する研究における, フィールドワーク研究と実験研究の位置づけ

トも安価であり, 開発途上国のよらな経済的に水質浄化 に多くのコストを掛けられない国々でも導入が可能であ る。フィールドワークでは複数の毒性重金属による複合 污染が明らかになっていることから，同時に複数の重金 属を吸着できる新たなハイドロタルサイト様化合物を合 成する必要がある。様々な検討の結果, MF-HT が最も 有効な化合物であることを見出している。上述したよう に，MF-HT はヒ素のみならず，鉄やバリウムも同時に 除去可能であり, 現在は様々な複合污染に対応した浄化 システムの構築を目指している。吸着試験は人工的に再 現させた污染水を使用して行らが, 最終的には実際の污 染井戸水を使用した試験が必要となる。筆者らは小規模 の（少量の）井戸水による実証試験を実施して打り, 前 述したよらに有効な結果が得られている。今後は, より 大規模な実証試験を現地にて行い, 実際に居住者の生活 に利用可能かどらかをテストする必要がある。また，よ り長期的な視野としては, 長期にわたって浄化システム を利用した人々に対して重金属によって誘発された疾患 の発症リスクがどのように推移するのかを検証しなけれ ばならない。

\section{おわりに}

安全な水の確保は, 人類が安全で幸福な生活を維持す るための最も重要な点であり, 最低限保証されるべきで ある。にもかかわらず，これらの安全と幸福を脅かされ ている地域が地球上に多数存在している。飲用水の重金 属污染は極めて重大な問題であり, 速やかに解決される べきではあるが，実際には政治・経済・社会・科学，様々 な分野の様々な要因から, 多くの問題が未解決のままで
ある。衛生学は上記の問題解決へのアプローチには極め て有効な学問である。フィールドワークを基本とした研 究は環境因子と疾患の因果関係を見出し，その危険性を 指摘することが可能である。疾患の発症メカニズムや予 防法は, フィールドワークによって得られた知見をベー スとして実験研究を行らことで明らかにすることが可能 であり,フィールドワーク研究を十全に行い, 尚且つ実 験研究をこれまで以上に推進していくことが, 衛生学に 扣いて必要である。衛生学に拈けるフィールドワーク研 究の充実に比べて，実験研究は未だ十分に実施されてい るとはいえず，フィールドワーク研究と実験研究を衛生 学に拈ける「両輪」として実施することが, 今後更に増 えるであろら，様々な問題の解決に必須である。安全な 水をより多くの人々が享受できる社会を構築するため に, 衛生学といら分野に拈いて, フィールドワークと実 験研究両方を実践していくことが重要である。

\section{謝辞}

本研究の一部は, 科学研究費補助金 (25340052, 26460798, 25-40080), Lydia O’Leary Memorial Foundation, Kurita Water and Environment Foundation の助成を得 て行われた。

利益相反なし

\section{文献}

( 1 ) Fernandez-Luqueno F, Lopez-Valdez F, Gamero-Melo P, Luna-Suarez S, Aguilera-Gonzalez E, Martinez A, et al. 
Heavy metal pollution in drinking water-a global risk for human health: A review. Af J Envi Sci Tech 2013;7:567584.

(2) Berg M, Stengel C, Pham TK, Pham HV, Sampson ML, Leng $M$, et al. Magnitude of arsenic pollution in the Mekong and Red River Deltas - Cambodia and Vietnam. Sci Total Environ 2007;372:413-425.

( 3 ) Chowdhury UK, Biswas BK, Chowdhury TR, Samanta G, Mandal BK, Basu GC, et al. Groundwater arsenic contamination in Bangladesh and West Bengal, India. Environ Health Perspect 2000;108:393-397.

(4) IARC. Some drinking-water disinfectants and contaminants, including Arsenic. Monogr Eval Carcinog Risk Chem Hum 2004;84:68-70, 223-226.

( 5 ) Kato M, Kumasaka MY, Ohnuma S, Furuta A, Kato Y, Shekhar HU, et al. Comparison of Barium and Arsenic Concentrations in Well Drinking Water and in Human Body Samples and a Novel Remediation System for These Elements in Well Drinking Water. PLoS One 2013;8:e66681.

(6) Kumasaka MY, Yamanoshita O, Shimizu S, Ohnuma S, Furuta A, Yajima I, et al. Enhanced carcinogenicity by coexposure to arsenic and iron and a novel remediation system for the elements in well drinking water. Arch Toxicol 2013;87:439-447.

( 7 ) Tamura H, Ohgami N, Yajima I, Iida M, Ohgami K, Fujii N, et al. Chronic exposure to low frequency noise at moderate levels causes impaired balance in mice. PLoS One 2012; 7:e39807.

( 8 ) Thang ND, Yajima I, Kumasaka MY, Ohnuma S, Yanagishita $\mathrm{T}$, Hayashi R, et al. Barium promotes anchorage-independent growth and invasion of human $\mathrm{HaCaT}$ keratinocytes via activation of c-SRC kinase. PLoS One 2011;6:e25636.

( 9 ) Thang ND, Yajima I, Ohnuma S, Ohgami N, Kumasaka MY, Ichihara G, et al. Enhanced constitutive invasion activity in human nontumorigenic keratinocytes exposed to a low level of barium for a long time. Environ Toxicol 2015; 30:161-167.

(10) Yajima I, Uemura N, Nizam S, Khalequzzaman M, Thang ND, Kumasaka MY, et al. Barium inhibits arsenic-mediated apoptotic cell death in human squamous cell carcinoma cells. Arch Toxicol 2012;86:961-973.

(11) Kato M, Kumasaka MY, Takeda K, Hossain K, Iida M,
Yajima I, et al. L-cysteine as a regulator for arsenic-mediated cancer-promoting and anti-cancer effects. Toxicol In Vitro 2011;25:623-629.

(12) Kato M, Onuma S, Kato Y, Thang ND, Yajima I, Hoque M, et al. Toxic elements in well water from Malaysla. Toxicol Environ Chem 2010;92:1609-1612.

(13) Kumasaka MY, Yajima I, Ohgami N, Naito H, Omata Y, Kato M. Commentary to Krishna et al. (2014): Brain deposition and neurotoxicity of manganese in adult mice exposed via the drinking water. Arch Toxicol 2014;88: $1185-1186$

(14) Thang ND, Yajima I, Kumasaka MY, Kato M. Bidirectional functions of arsenic as a carcinogen and an anti-cancer agent in human squamous cell carcinoma. PLoS One 2014; 9:e96945.

(15) Ohgami N, Hori S, Ohgami K, Tamura H, Tsuzuki T, Ohnuma $\mathrm{S}$, et al. Exposure to low-dose barium by drinking water causes hearing loss in mice. Neurotoxicology 2012; 33:1276-1283

(16) Boukamp P, Petrussevska RT, Breitkreutz D, Hornung J, Markham A, Fusenig NE. Normal keratinization in a spontaneously immortalized aneuploid human keratinocyte cell line. J Cell Biol 1988;106:761-771.

(17) Kaur S, Wang F, Venkatraman M, Arsura M. X-linked inhibitor of apoptosis (XIAP) inhibits c-Jun N-terminal kinase 1 (JNK1) activation by transforming growth factor beta1 (TGF-beta1) through ubiquitin-mediated proteosomal degradation of the TGF-beta1-activated kinase 1 (TAK1). J Biol Chem 2005;280:38599-38608.

(18) Tang G, Minemoto Y, Dibling B, Purcell NH, Li Z, Karin M, et al. Inhibition of JNK activation through NF-kappaB target genes. Nature 2001;414:313-317.

(19) Gillman GP. A simple technology for arsenic removal from drinking water using hydrotalcite. Sci Total Environ 2006;366:926-931.

(20) Lazaridis NK, Asouhidou DD. Kinetics of sorptive removal of chromium(VI) from aqueous solutions by calcined $\mathrm{Mg}$ Al-CO(3) hydrotalcite. Water Res 2003;37:2875-2882.

(21) Turk T, Alp I, Deveci H. Adsorption of As(V) from water using Mg-Fe-based hydrotalcite (FeHT). J Hazard Mater 2009;171:665-670 